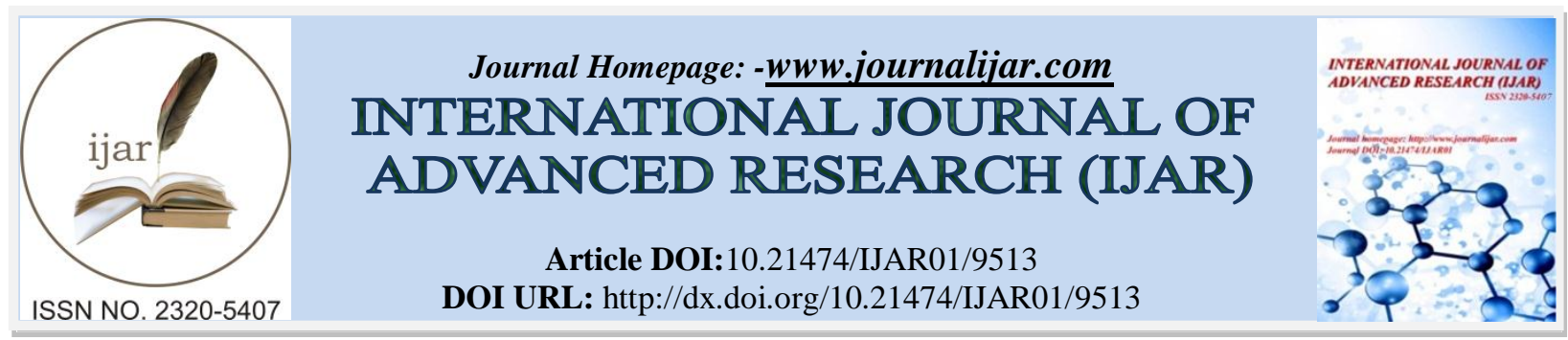

RESEARCH ARTICLE

\title{
THE EFFECT OF STRATEGIC LEADERSHIP, ORGANIZATIONAL CULTURE, AND LEARNING ORGANIZATION ON GOOD CORPORATE GOVERNANCE AND ORGANIZATIONAL PERFORMANCE IN AGENCY OFFICE OF PT AIA FINANCIAL EAST INDONESIA AREA.
}

\author{
Santoso ${ }^{1}$, Prof. Drs. Ec. Budiman Christiananta ${ }^{2}$ and Lena Ellitan ${ }^{3}$. \\ Widya Mandala Catholic University Surabaya, School of Post Graduate, Surabaya, Indonesia.
}

\section{Manuscript Info}

\section{Manuscript History}

Received: 06 June 2019

Final Accepted: 08 July 2019

Published: August 2019

\section{Key words:-}

strategic leadership, organizational culture, learning organization, good corporate governance, organizational performance.

\begin{abstract}
This study aims to examine the effect of strategic leadership, organizational culture, and learning organizations on organizational performance through good corporate governance. This study used 100 leaders at AIA Financial in the East Indonesia region. The test method is carried out to test the seven hypotheses formulated in this study using partial least square. The results of the study show that the three strategic leadership variables, organizational culture, and learning organizations have a significant effect on good corporate governance. Further testing then found that strategic leadership had no significant effect on organizational performance. However, organizational culture, learning organizations, and good corporate governance have a significant effect on organizational performance.
\end{abstract}

Copy Right, IJAR, 2019,. All rights reserved.

\section{Introduction:-}

Further increasing the role of real and non-real investment is also to increase economic competitiveness by carrying out economic arrangements that can encourage community initiatives in economic activities, especially for the middle to lower income groups. One of them is by increasing the role of Non-Bank Financial Institutions (NBFIs) such as insurance, pension funds, finance companies, venture capital companies and pawnshops. The institutions have not had a significant role in becoming a long-term funding source. This is evidenced by data showing that total assets collected through insurance, pension funds, finance companies, venture capital companies and new pawnshops are around 10.2 percent of GDP when compared to banks which have reached around 47.3 percent of GDP (RPJM 2010-2014).

One important part of the NBFI is insurance, where insurance can be a supporter in increasing real and non real investment in Indonesia. Insurance in Indonesia is currently directly proportional to per capita income in Indonesia, meaning that the higher income and assets that are owned because with the increase in income and assets, it will be accompanied by greater risk, therefore protection of these risks is needed through insurance. Own insurance provides welfare and peace which is the main promise of insurance (Arjono, 2008). This insurance activity is also supported by an increase in the economy, of course, followed by an increase in the per capita income of the Indonesian people which causes the ability to pay insurance premiums which are also increasing.

Insurance is a form of risk transfer where a risk transferred to another party is economically very important. Insurance institutions are very helpful in bearing a variety of risks that can cause losses in the implementation of

Corresponding Author:-SantosoS.T., M.M.

Address:-Widya Mandala Catholic University Surabaya, School of Post Graduate, Surabaya, Indonesia. 
development, the need for the presence of insurance business is also felt by the business world considering that on one hand there are various risks that consciously and rationally can disturb the continuity of business activities. Insurance companies as service companies, on the one hand sell services to customers, while on the other hand, insurance companies are investors from community savings to productive investments. Indirectly insurance or insurance institutions are risk transfer institutions (Hartono, 1999).

Insurance company PT AIA Financial (AIA) began pioneering insurance business in Indonesia in 1984. In 1998 when Asia experienced a crisis, insurance companies in Indonesia, including AIA, still posted profits despite declining. AIA in Indonesia is a subsidiary of AIA Group. AIA offers a variety of insurance products, including insurance under Sharia principles, which include life insurance, health insurance, personal accident insurance, insurance associated with investment, employee welfare programs, severance programs, and Pension Fund programs (DPLK). These products are marketed by more than 10,000 experienced and professional salespeople through various distribution channels.

Implementation and management Good corporate governance that is good or better known as good corporate governance is a concept that emphasizes the importance of the rights of shareholders to obtain information correctly, accurately and on time. In addition, it also shows the company's obligation to disclose all company financial performance information accurately, on time and transparently. Therefore both public companies and private companies must view good corporate governance not as mere accessories but as an effort to improve company performance and value., Tjager (2003) in Darmayati (2004).

Berghe and Ridder (1999) in their research linking company performance with good corporate governance is not easy to do. Some studies show no relationship between good corporate governance and company performance. For example, the study of Daily et al (1994) and the results of a survey of the Confederation of British Industry / CBI, Young (2000) which analyzed several studies that linked good corporate governance with company performance. On the other hand, based on the results of the study, Berghe and Ridder stated that companies that have poor performance are caused by poor governance. This statement is supported by Gompers et al (2003) research in Darmayati (2004) who found a positive relationship between the index of good corporate governance and long-term corporate performance. However, Bhatt and Bhatt (2017) find that good corporate governance has no significant effect on performance. This then became one of the research gaps in this study.

From the description above shows that strategic leadership, organizational culture, learning organizations, good corporate governance, and organizational performance are still debated among researchers. Therefore, this study seeks to close the gap of previous studies by proposing a comprehensive strategic system model involving: (1) direct effect models Strategic Leadership, Organizational Culture, Learning Organizations on Corporate Performance (2) Intervening effect models Governance good company at the agency office at PT AIA Financial, Indonesia.

\section{Literature Review \\ Resource Based View}

Resource Based View (RBV) or Resource Based Theory (RBT) was introduced by Penrose in 1959 and developed until now as a field of management studies specifically regarding Organizational Performance. Madhani (2009) describes the development of RBV from 1959 to 1997 that internal resources and capabilities are important factors that influence sustainable competitiveness and high-performance organizations. Three types of resource categories according to Barney (1991), namely physical capital resources such as factories and equipment, human capital resources such as experience and expertise, and organizational capital resources such as the formal structure of the organization.

\section{Agency Theory}

Agency theory was developed by Michael Johnson, a Professor from Harvard. In agency theory, it is seen that company management as agents for shareholders act with full awareness for their own interests, not as wise and wise and fair to shareholders (stewardship theory). Stewardship theory is built on philosophical assumptions about human nature, namely that human beings are essentially trustworthy, able to act responsibly with integrity, and honesty towards others. In other words, this theory considers humans to be trusted to act as well as possible for the interests of the public in general and stakeholders in particular. 


\section{Strategic Leadership}

Transactional leadership is the relationship between leaders and subordinates based on a series of bargaining activities between the two, Burns (1978). Bass and Avolio (1993) suggest that strategic leadership is a process within a group. To be able to lead, leaders must do something in groups. Leadership is more than just authority. Although the position of the formalized authority may greatly encourage the leadership process, just occupying that position does not mark a person as a leader.

Strategic leadership is more directed at the transformational leadership model than transactional leadership. In the measurement of this study five out of sixteen strategic leadership indicators according to Burns (2008) with consideration that these five indicators reflect the characteristics, values, and behavior of committed strategic leadership.

\section{Organizational Culture}

Organizational culture is defined according to Hussein, et al (2016) which is the values and beliefs that are generated by company leaders to direct the organization and become a guideline for the organization. This is then translated by employees and lower-level managers into behaviors and actions in daily activities. According to Yesil and Kaya (2013), organizational culture is a set or complex set of ideologies, symbols, and core values that are shared with all elements of the company and this determines how to do business.

Organizational culture itself is a social glue that binds all members of the organization and combines and unites them in organizational activities (Adewale and Anthonia, 2013). As a social glue, the organizational culture serves to recruit new employees and retain existing employees who have good performance. In this case, organizational culture can affect the human resource management system within the company.

\section{Learning Organization}

Lately some experts as quoted by Beardwell and Holden (2001) provide a broader definition of learning organizations, namely organizations that facilitate learning for all members and transform consciously in the context of the organization. The intent and purpose of using both individual, group and organizational learning processes is to transform organizations to meet stakeholder satisfaction. According to Schulz (2006), learning organizations are defined as the process by which an organization acquires new knowledge from its environment. According to Garcia-Morales (2006), learning organizations are a process of finding and creating knowledge, sharing knowledge, and applying that knowledge.

\section{Good Corporate Governance}

One of the principles regulated in good corporate governance is transparency. Where the shareholders have the right to receive information correctly and in a timely manner about the company and can participate in decision-making regarding fundamental changes to the company and participate in obtaining a share of the company's profits. Based on the functions of directors in the company, the directors basically run the interests of the shareholders, including continuously and as strongly as the power of managing the company well to achieve the company's objectives, including in notifying shareholders regarding the company's development, even though the information provided by the company in making decisions outside the company.

The Board of Directors is in charge of managing the company and is obliged to account for the implementation of its duties to shareholders in the term of appointment of directors who manage the company must consist of people who are good, professional and experienced so that they can carry out their duties in the company's interests. fulfill the rights of stakeholders based on applicable provisions and laws and regulations. This principle if implemented in good corporate governance will reflect the principle of fairness.

Implementation Good corporate governance is reflected in the principle of accountability, regarding the clarity of functions, implementation, and accountability of each company organ (General Meeting of Shareholders, Commissioners, and Directors) that enables effective management of the company. Accountability refers to the obligations of a director or other work organ related to the implementation of the authority he has and / or the implementation of the responsibilities that the company imposes on him. The implementation of the principle of responsibility is reflected also from the duties of directors who guarantee that their business activities are carried out based on sound corporate principles, fulfilling obligations to the government in accordance with applicable regulations, cooperating actively for mutual benefits, and striving to contribute significantly to society. 


\section{Organizational Performance}

Wheelen and Hunger (2012) define performance as a result of activity. Performance is a process of evaluation and control of strategic management. The performance of a company can be measured by various indicators, both financially and non-financially. Performance is a continuous and flexible process that involves managers and the people they manage acting as partners in determining how they work best to achieve the desired results. . According to Carton (2004), performance is a measure of changes in the financial condition of an organization, or financial results resulting from management decisions and the implementation of those decisions made by members of the organization. The steps used to represent performance are chosen based on the state of the organization being observed. The steps chosen represent the results achieved, good or bad.

\section{Strategic Leadership and Good Corporate Governance}

According to Boggust, et al (2002), strategic leadership factors are an important key in implementing good corporate governance where leadership is able to bring change to the organization. Some studies try to combine the context of strategic leadership and good corporate governance (Davies, 2006; Gabrielsson; Huse, and Minichilli, 2007). Anggiriawan and Wirakusuma (2015) research concludes in his findings that the application of good corporate governance is needed by leaders in determining their leadership style in improving the management system of an organization as a whole. This proves that strategic leadership has a significant effect on good corporate governance. Based on the review of the theory, hypothesis 1 is formulated, namely:

H1: Strategic leadership has a significant effect on good corporate governance

\section{Organizational Culture and Good Corporate Governance}

According to Storz (1999), organizational culture is an important factor in shaping behavior and practice in conducting business, including in terms of shaping good corporate governance. According to Pryor (2007) that cultural characteristics determine a system within a company that forces a company to apply certain principles. Thus, if the culture within the company supports the creation of good corporate governance, then good corporate governance within the company will also increase. Anggiriawan and Wirakusuma's (2015) research concludes in his findings that good corporate governance is a management or monitoring controller in carrying out its operational activities, so that finally it can take the form of organizational culture which has implications for high performance improvement. This proves that organizational culture has a significant effect on good corporate governance. Based on the review of the theory, hypothesis 2 is formulated, namely:

\section{H2: Organizational culture has a significant effect on good corporate governance}

\section{Learning Organization and Good Corporate Governance}

According to Cucculelli (2016), to be able to adopt good corporate governance properly there is a need for a learning process, so that in this case the learning organization is needed. This is also supported by Lauer (2017) who states that the application of good corporate governance cannot be done instantly so that it requires the existence of a learning organization. This shows the importance of the role of learning organizations in shaping and building good corporate governance within a company. Research by Kearney and Kruger (2013) found that there was a relationship between learning organizations and good corporate governance. This is because the organization always learns to apply the principles of good corporate governance well. Based on a review of the theory, hypothesis 3 is formulated, namely:

H3: Learning organizations have a significant effect on good corporate governance

\section{Strategic Leadership and Organizational Performance}

The success of organizational performance depends heavily on the good and right behavior of its members. Leadership greatly helps businesses to maintain the best performance in their daily operations. Organizations will be effective if they find a balance between the demands and needs of various stakeholders (owners, employees, customers, and communities). Some research shows that leadership influences company performance. Research conducted by Martin et al. (2014) found that there was a positive relationship between leadership style and company performance. Democratic leaders encourage creativity and innovation of workers, so it can be concluded that leadership contributes to effective performance in organizations. This is supported by Nthini (2013); Kitonga et al. (2016) that effective strategic leadership influences company performance. Companies that have strategic leadership will be able to produce higher corporate performance. Based on the review of the theory, hypothesis 4 is formulated, namely:

H4: Strategic Leadership has a significant effect on Organizational Performance 


\section{Organizational Culture and Organizational Performance}

According to Cameron and Quinn (2006), organizational culture is an important element in explaining and improving company performance. When an employee in an organization joins they have different values and beliefs. However, over time in the organization they learn to behave in accordance with organizational culture. Organizational culture has a profound impact on employee performance which can lead to improved productivity and improve company performance. Hogan and Coote (2014) state that organizational culture can improve company performance. A slightly different finding is the Nikpour (2017) study that organizational culture has an indirect impact on company performance through mediating organizational commitment. However, more research supports that organizational culture influences performance (Ovidiu, 2014; Mujeeb, 2011). Based on a review of the theory, hypothesis 5 is formulated, namely:

H5: Organizational culture has a significant effect on Organizational Performance

\section{Learning Organization and Organizational Performance}

According to Attewel (1992), the success of overall business performance requires adjustments to business processes, thus requiring the company's ability to modify and master aspects of the business. According to Harris (2008), learning organizations can encourage better performance, through the use of knowledge. The company's ability to be flexible and sensitive to changes in the technological environment that occur continuously depends on the learning organization. According to Cegarra-Navarro et al. (2007), learning organizations also contribute to employee productivity and encourage other important capabilities in achieving successful corporate performance. Lin and Lee (2005) found that learning organizations have a significant effect on company performance. This is supported by the study of Migdadi et al., 2016. Other studies by Uniati and Monica (2014), Faozan, Haris (2009) also found that learning organizations influence organizational performance. Based on the review of the theory, hypothesis 6 is formulated, namely:

H6: Learning organizations have a significant effect on Organizational Performance

\section{Good Corporate Governance and Organizational Performance}

According to Iwasaki (2008), Good Corporate Governance is an important factor in gaining competitive advantage. According to Bhagat and Bolton (2008), corporate governance regulations and guidelines issued by government agencies and international bodies, when implemented, help companies specifically and the country, in general, to attract foreign investment. The corporate governance code will ensure investor safety, protect it from corporate scandals. Over time, it has been recognized that there is no single measure for all approaches to achieving effective governance. Research conducted by Anggiriawan, Putu Budi (2015) concluded that the implementation of Good Corporate Governance had an effect on organizational performance. In Alvin's research, Kho (2015) states that good corporate governance is one of the keys for companies to become better companies. Maria (2010); Ndaruningpuri (2006); Azlina and Amelia (2014) also stated in this study. Based on the review of the theory, hypothesis 7 is formulated, namely:

H7: Good corporate governance has a significant effect on Organizational Performance

\section{Research Methods:- \\ Population and Sample}

Population is a generalization area consisting of subjects / objects that have certain qualities and characteristics set by the researcher to be studied and conclusions drawn later (Sugiono, 2017). The population is also intended for the whole group, events, or something interesting to conduct an investigation (Sekaran, 2003). In each study, the population chosen is closely related to the problem being studied. In this study the focus was on using AIA Insurance with consideration of accessibility and closeness of researchers who had worked at AIA Insurance. The population in this study were marketers from the AIA Financial agency marketing office in the eastern part of Indonesia with samples representing the population, namely Agency Directors, Senior Agency Managers, and Agency Managers in the marketing office classified as the Gold Agency. Gold Agency Criteria at AIA Financial is a marketing agency office that has been operating for more than ten years, namely the performance of organizations that have been operating before 2010. The total number of respondents that can be obtained is from 37 Gold Agency Marketing offices (unit of analysis).

The sample size is determined based on the Maximum Likelihood (ML) method according to the minimum requirements according to (Ferdinand, 2014), namely the sample data size of the research that is suitable for the needs of SEM-PLS analysis is 100 to 200. In this study not all populations will be used as samples. Sampling is done based on the willingness of the Head of the Office of the Marketing Agency concerned, namely the Diretor 
Agency / Senior Agency Manager. To get a sample, a sample technique is needed. The sampling technique used in this study is random sampling technique with the calculation of sample size from the population using Simple Random Sampling. Based on Slovin formula, this research have 27 agency office as sample. From each business unit selected as a sample, respondents were taken according to the size of the population of the business unit based on the position of Agency Directors, Senior Agency Managers, and Agency Managers (Leaders). The total number of respondents in this study that can be obtained is 100 respondents, which means that the assumptions for sample size have been fulfilled.

\section{Statistic Method:-}

This research uses partial least square (PLS) analysis technique is used. Partial Least Square (PLS) was first developed by Herman Wold as a general method for estimating path models between latent construct relationships that are indirectly measured by various indicators. This model was developed as an alternative in research for situations where a weak theoretical basis in the relationship between variables hypothesized with large research data scales, but not infrequently also used in research that the relationship between variables is very complex with a small data scale. PLS is an alternative SEM method that can be used to overcome problems in the relationship. PLS assumes that research data is free of distribution, meaning that research data does not refer to one particular distribution. (Yamin and Kurniawan, 2009).

PLS is a variant-based SEM statistical method designed to solve multiple regression when specific data problems occur, such as small research sample sizes, missing data and multicollinearity. Ghozali (2006) explains that PLS can work for a model of latent extract relations and manifest variables (also called indicator variables) that are reflective and formative. PLS is an alternative method with a variance-based approach or a component that is predictionoriented. In addition, PLS works on a structural model that is recursive, so that an unidentified, under-identified or over-identified problem will not occur. Factors that cannot be determined (indeterminacy factor), namely the existence of more than one factor contained in a set of indicators for a variable. Particularly formative indicators do not require a common factor so that there will always be composite latent variables. In this case the latent variable is a linear combination of the indicators.

Estimating parameters in PLS includes 3 things, namely (Ghozali, 2006)

1. Weight estimate used to score latent variables.

2. Estimated path (path estimate) that connects between latent variables and estimated loading between latent variables and indicators.

3. Means and parameter locations (regression constant, intercept) for indicators and latent variables.

To obtain these three estimates, PLS uses a three-stage iteration process and each iteration stage produces estimates. The first stage produces a weight estimate, the second stage produces an estimate for the inner model and outer model, and the third stage produces estimates of means and locations (constants). In the first two stages the iteration process is carried out with an approach deviation (deviation) from the means value (average). In the third stage, the estimation can be based on the original data matrix and / or the results of estimating weights and path coefficients in the second stage, the purpose of which is to calculate and location parameters.

\section{Findings}

\section{Respondent Profile}

The respondents in the study consisted of 100 agency leaders from the AIA Financial agency marketing office in the eastern part of Indonesia. The value of the variables used in the analysis is the average value of each indicator from the respondent's response. The questionnaires distributed in this study were 100 sets, of which 100 were returned. Thus, the rate of return in this study is 100 percent. Questionnaires that are returned and filled with 100 sets are assumptions for the sample size that has been fulfilled. The profile of the research respondents consisted of age, gender and formal education that had been taken.

Table 1:-Respondent Age

\begin{tabular}{|c|c|c|}
\hline Age & Amount & Percentage \\
\hline $26-35$ & $\mathbf{1 9}$ & $\mathbf{1 9 \%}$ \\
\hline $36-45$ & $\mathbf{4 8}$ & $\mathbf{4 8 \%}$ \\
\hline $46-55$ & $\mathbf{2 5}$ & $\mathbf{2 5 \%}$ \\
\hline$>55$ & $\mathbf{8}$ & $\mathbf{8 \%}$ \\
\hline
\end{tabular}




\begin{tabular}{l|l|r} 
Total & $\mathbf{1 0 0}$ & $\mathbf{1 0 0 \%}$ \\
\hline
\end{tabular}

Characteristics of respondents based on age, namely: 26-35 years as many as 19 respondents (19 percent), 36-45 years as many as 48 respondents ( 48 percent), $46-55$ years as many as 25 respondents ( 25 percent), and $>55$ years as many as 8 respondents ( 8 percent) can be seen in Table 4.1. AIA Financial Indonesia's agency leader is mostly $36-$ 45 years old. At the age of 36-45 years is a productive age, work experience is sufficient to lead, run and oversee the company's daily operations.

Table 2:-Respondent Sex

\begin{tabular}{|c|c|c|}
\hline Sex & Amount & Percentage \\
\hline Male & $\mathbf{3 6}$ & $\mathbf{3 6 \%}$ \\
\hline Female & $\mathbf{6 4}$ & $\mathbf{6 4 \%}$ \\
\hline Total & $\mathbf{1 0 0}$ & $\mathbf{1 0 0 \%}$ \\
\hline
\end{tabular}

Characteristics of respondents of research based on sex, namely Men as many as 36 respondents (36 percent), and Women as many as 64 respondents (64 percent) can be seen in Table 4.2. In Table 4.2 the AIA Financial Indonesia high staff are mostly female.

Table 3:-Respondent Education

\begin{tabular}{|c|c|c|}
\hline Education & Amount & Percentage \\
\hline High School & $\mathbf{3}$ & $\mathbf{3 \%}$ \\
\hline S1 & $\mathbf{9 5}$ & $\mathbf{9 5 \%}$ \\
\hline S2 & $\mathbf{2}$ & $\mathbf{2 \%}$ \\
\hline Total & $\mathbf{1 0 0}$ & $\mathbf{1 0 0 \%}$ \\
\hline
\end{tabular}

The characteristics of the respondents were based on recent education, namely: graduating from high school (SMA) as many as 3 respondents ( 3 percent), Strata 1 (S1) as many as 95 respondents (95 percent), and Strata 2 (S2) as much as 2 responses ( 2 percent) seen in Table 4.3. the majority of respondents graduated from S1 education, because the respondent's position as an agency leader in addition to requiring work experience as well as sufficient skills and knowledge. The respondent's education level is adequate because most of them have a Bachelor degree (S1).

\section{Structural Equation Test}

After testing the validity and reliability of all latent variables that have valid and reliable results, normal multivariate data, no singularity and no outliers, then the latent variable can be continued in the analysis with the form of path diagram presented, in Figure below:

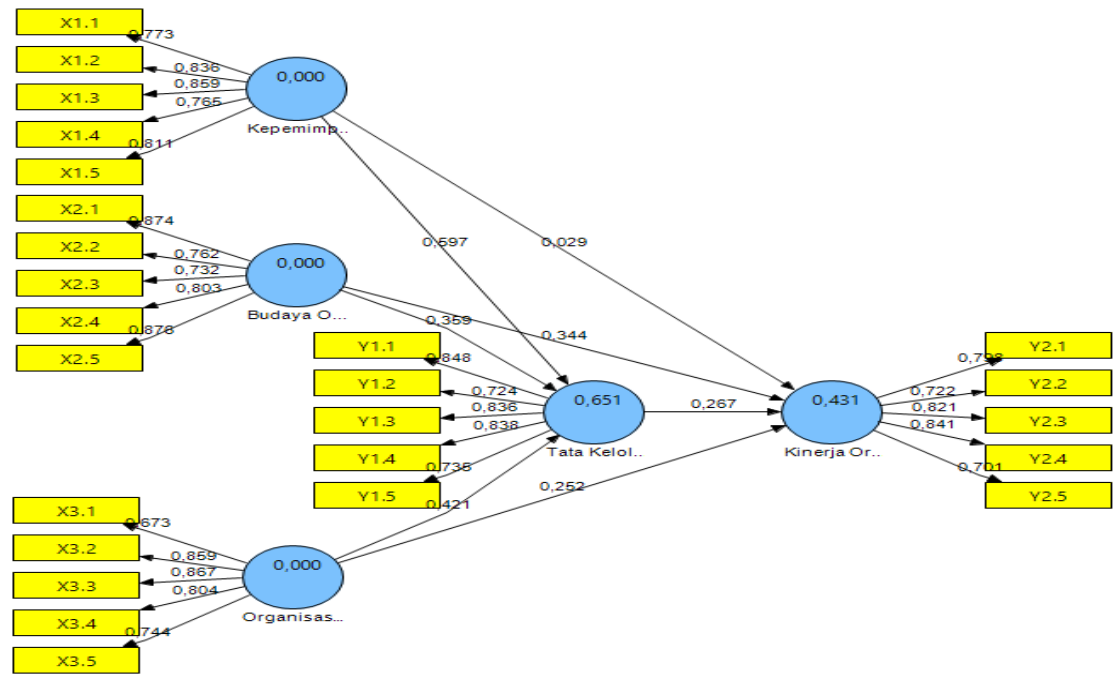

Figure 1:-Research Diagram Path 


\section{Hypotheses Test}

The results of the inner path coefficient along with the full significance values are shown in the table below.

\begin{tabular}{|c|c|c|c|c|}
\hline No & Hipothesis & Explanation & T - statistics & Result \\
\hline 1 & $\mathrm{H}_{1}$ & $\begin{array}{l}\text { Strategic Leadership (X1) } \rightarrow \text { Good Corporate } \\
\text { Governance (Y1) }\end{array}$ & 12,927 & Accepted \\
\hline 2 & $\mathrm{H}_{2}$ & $\begin{array}{l}\text { Organizational Culture (X2) } \rightarrow \text { Good } \\
\text { Corporate Governance (Y1) }\end{array}$ & 5,473 & Accepted \\
\hline 3 & $\mathrm{H}_{3}$ & $\begin{array}{l}\text { Learning Organization }(\mathrm{X} 3) \rightarrow \text { Good } \\
\text { Corporate Governance }(\mathrm{Y} 1)\end{array}$ & 7,131 & Accepted \\
\hline 4 & $\mathrm{H}_{4}$ & $\begin{array}{l}\text { Strategic Leadership (X1) } \rightarrow \text { Organizational } \\
\text { Performance (Y2) }\end{array}$ & 0,250 & Rejected \\
\hline 5 & $\mathrm{H}_{5}$ & $\begin{array}{l}\text { Organizational Culture }(\mathrm{X} 2) \rightarrow \\
\text { Organizational Performance (Y2) }\end{array}$ & 3,312 & Accepted \\
\hline 6 & $\mathrm{H}_{6}$ & $\begin{array}{l}\text { Learning Organization }(\mathrm{X} 3) \rightarrow \text { Organizational } \\
\text { Performance }(\mathrm{Y} 2)\end{array}$ & 3,237 & Accepted \\
\hline 7 & $\mathrm{H}_{7}$ & $\begin{array}{l}\text { Good Corporate Governance (Y1) } \rightarrow \\
\text { Organizational Performance (Y2) }\end{array}$ & 2,377 & Accepted \\
\hline
\end{tabular}

\section{Discussion:-}

A direct relationship occurs between exogenous latent variables (strategic leadership, organizational culture, learning organizations) with endogenous latent mediation variables (good corporate governance) and endogenous latent variables (organizational performance). It can be explained that the direct effects of exogenous latent variables on endogenous latent variables. Organizational culture (X2) has the greatest direct effect on organizational performance (Y2) and then strategic leadership (X1) on good corporate governance (Y1). The results of data analysis show that the direct effect of organizational culture has the greatest direct effect on organizational performance, that the higher the organizational culture the better the performance of the organization. This finding is in line with Nikpour's research (2017), stating that there is a positive relationship between organizational culture and achievement of organizational performance. Furthermore, the influence of strategic leadership also has the greatest effect on good corporate governance. The better strategic leadership the better the good corporate governance of the company. This is in line with previous research by Anggiriawan and Wirakusuma (2015) in his research explaining that for good corporate governance to be successful, strategic leadership is needed supported by top management in the long run.

Indirect relationships occur between exogenous variables (strategic leadership, organizational culture, learning organizations) with endogenous intervening latent variables (good corporate governance) and endogenous latent variables (organizational performance). It can be explained the indirect effect of exogenous latent variables on endogenous latent variables. Organizational culture (X2) has the largest indirect effect on good corporate governance (Y1) on organizational performance (Y2). From the results of the analysis, it can be explained that organizational culture and good corporate governance have a significant indirect effect on the positive direction of organizational performance. The better organizational culture and good corporate governance in a company will improve organizational performance. This research reinforces previous research by Nikpour (2017) and Hogan and Coote (2014) who found that organizational culture is very important for achieving organizational performance.

Total influence is the sum of direct and indirect effects between exogenous latent variables Strategic Leadership (X1), Organizational Culture (X2) and Learning Organization (X3) with endogenous latent variables intervening Good corporate governance (Y1) and endogenous latent variables Organizational performance ( Y2). It can be explained the total effect of the exogenous latent variables on endogenous latent variables. The organizational culture variable (X2) gives the largest total effect on organizational performance (Y2). Meanwhile good corporate governance (Y1) has the smallest total effect on organizational performance (Y2). In contrast to previous research, in this study found results that did not support the results of previous studies where strategic leadership did not provide significant results on organizational performance. That the higher or lower strategic leadership will not have an effect on organizational performance.

\section{Conclusion:-}

Based on the results of the study analysis and discussion, conclusions can be taken as follows: 
1. Strategic leadership has a significant effect on the positive direction of good corporate governance. Thus strategic leadership directly influences good corporate governance, which means that whenever there is an increase in strategic leadership, it will improve good corporate governance. This shows that if a leader has motivational abilities, leaders who have the ability to manage change, leaders who have the ability to clarify ambiguity and uncertainty, leaders who have the ability to delegate tasks, leaders who have a flexible ability to deal with conditions that are dynamic will be able to build consistency Good corporate governance. The results of this study are in line with the results of Anggiriawan and Wirakusuma (2015)

2. Organizational culture has a significant effect with a positive direction towards good corporate governance. Thus organizational culture directly influences good corporate governance, which means that whenever there is an increase in organizational culture, it will affect the improvement of good corporate governance. This shows that the better the organizational culture at AIA Financial Indonesia, the better corporate governance will be for the company. The results of this study are in line with research by Anggiriawan and Wirakusuma (2015)

3. Learning organizations have a significant effect with a positive direction towards good corporate governance. Thus the learning organization has a direct influence on good corporate governance, which means that every increase in the learning organization will improve good corporate governance. The results of this study indicate that the better learning organizations in the AIA Financial Indonesia company will provide an influence in the form of improving the quality of good corporate governance to ensure the principle of professional management of the company. The results of this study are in line with Kearney and Kruger (2013).

4. Strategic leadership has no significant effect on organizational performance. Thus strategic leadership has no effect on organizational performance, which means that whenever there is an increase or decrease in strategic leadership it will not affect company performance. The results of this study indicate that strategic leadership does not affect organizational performance at AIA Financial Indonesia. The results of this study are not in line with previous studies conducted by Martin et al. (2014) and Kitonga et al. (2016).

5. Organizational culture has a significant effect with a positive direction on organizational performance. Thus the organizational culture has a direct effect on organizational performance, which means that every increase in organizational culture will increase organizational performance. The results of this test indicate that the success of a company in improving organizational performance also depends on the organizational culture in the company. A good organizational culture will improve organizational performance. Companies must continue to maintain a conducive organizational culture that can be a means to increase the success of organizational performance in the future. The results of this study are in line with the findings of Hogan and Coote (2014) and Nikpour (2017).

6. Learning organizations have a significant effect with a positive direction on organizational performance. Thus the learning organization affects directly on organizational performance, which means that every increase in the learning organization will improve organizational performance. The results of this test indicate that the success of a company in improving organizational performance depends also on the learning organization in the company. If the company becomes a good learning organization, it will improve organizational performance. Companies must continue to maintain a conducive learning organization that can be a means to increase the success of organizational performance in the future. The results of this study are in line with the findings of Migdadi et al. (2016) and Uniati and Monica (2014)

7. Good corporate governance has a significant effect with a positive direction on organizational performance. Thus good corporate governance has a direct effect on organizational performance, which means that whenever there is an increase in good corporate governance, it will affect the improvement of organizational performance. The results of this study indicate that it is increasingly important for companies to implement good corporate governance on an ongoing basis, it can help contribute to organizational performance. The results of this study are in line with Ndaruningpuri (2006) and Azlina and Amelia (2014).

\section{Reference:-}

1. Adewale, O.O. \&Anthonia, A.A. (2013). Impact of Organizational Culture on Human Resource Practices: A Study of Selected Nigerian Private Universities. Jurnal of Competitiveness, Vol.5, Issue 4, pp. 115-133

2. Ahmady, Gholam Ali, AghdasNikooravesh, Maryam Mehrpour. (2016). Effect of organizational culture on knowledge management based on Denison model. Procedia - Social and Behavioral Sciences 230, pp. 387-395.

3. Arjono, Budi (2008). MenghadirkanKomisiPenjamin Polis. Media Asuransi, No.215, Tahun XXIX

4. Avery, C. (2008). Missing Links in Understanding the Relationship Between Leadership and Organisational Performance.

5. Azlina, Nur\& Amelia, Ira (2014). Pengaruh Good Governance danPengendalian Intern terhadapKinerjaPemerintahkabupatenPelalawan. JurnalAkuntansiUniversitasJember- Vol. 12 No.2 Des 2014. 
6. Barney, J. B. (1991). Firm resources and sustained competitive advantage. Journal of Management, 17, pp. 99120.

7. Bass, B.M (1990). Leadership and Performances beyond expectations. New York: The Free Press.

8. Bass, B., \&Avolio. (1993-Spring). Transformational Leadership and Organizational Culture. Public Administration Quartely, 17:1, pp. 112-122.

9. Beardwell, Ian \& Holden, Len (2001). Human Resource Management: A Contemporary Approach, London: Prentice Hall

10. Berghe L. V. \& Ridder L. D. (1999). International Standardization of Good Corporate Governance: Best Practices for the Board of Directors. Boston: Kluwer Academic Publisher.

11. Carmeli, A. danTishler, A. (2004). The Relationships between Intangible Organizational Elements and Organizational Performance. Strategic Management Journal, Vol. 25, pp. 1257-1278

12. Carton, R.B. (2004). Measuring Organizational Performance: An Exploratory Study. PhD (Partial Fulfilment). The University Of Georgia

13. Case, Karl. E dan Fair (2004). Principle of Economics. NY : Pearson.

14. Challgalla, N. Goutham\&Shervani, A. Tasaddug. (2006). "Dimensional and type of Supervisor Control: Effect on Sallesperson Performance and Satisfaction" Journal of Marketing, Vol. 60. January

15. Darmayati D. (2004). Hubungan Corporate Governance danKinerja Perusahaan. Simposiun Nasional Akuntansi VII, Denpasar.

16. David, Fred R. (2003). Strategic Management concepts nad Cases, 9th. International Edition, New Jersey: Prentice Hall.Inc.

17. Davidsson, P. (2004). Researching Entrepreneurship. New York: Springer Science.

18. Davies, A. (2006). Best practice in corporate governance: Building reputation and sustainable success. Aldershot,UK:Gower.

19. DiaconS.R.,\& Noel O’Sullivan. (1995). Does Corporate Governance Influence Performance? Some evidence from U.K. Insurance Company, Elsevier Inc. International Review of Low and Economics 15, pp 405-424

20. EffiezalAswadi Abdul Wahab, Anwar Allah Pitchay, Ruhani Ali. (2015). Culture, corporate governance and analysts forecast in Malaysia. Asian Review of Accounting, Vol. 23 Iss 3 pp. -

21. Elidio de Araujo (2013). PengaruhKepemimpinanStratejikdan Corporate Culture terhadapKinerja Perusahaan dengan Good Corporate Governance sebagaiVariabel Intervening. Disertasi. UKWMS

22. Faozan, Haris (2009). ArtiPenting Organizational Learning Dan BerbagaiHambatannya: SebuahWawasan Fundamental UntukMeningkatkanKinerjaOrganisasiPerangkat Daerah. Buku Accelerating Performance: KonsepdanAplikasi.

23. Ferdinand, A. (2014). MetodologiPenelitian. Semarang: Undip Press.

24. Finegold, D, Lawler III E.E., \& Conger J. (2001), Building a better board, Journal of Business Strategy, 22(6), pp. 33-37

25. Gabrielsson, J.,Huse,M. \&Minichilli, A. (2007). Understanding the leadership role of the board chair person through a team production approach. International Journal of Leadership Studies, pp. 3

26. Galbreath, Jeremy. (2005). Which resources matter the most to firm succes? An exploratory study of resourcebased theory. Journal Technovation 25, pp: 979-987.

27. Hogan, S.J. danCoote, L.V. (2014). Organizational Culture, Innovation, and Performance: A Test of Schein's Model. Journal of Business Research, Vol. 67(8), pp. 1609-1621

28. Hoskisson, R.A. (1999). Theory and research in a strategic management: Swing of a pendulum. Journal of Management 25(3), pp. 417-456.

29. Hitt, M.A. dan Ireland, R.D. (1999). Achieving and Maintaining Strategic Competitiveness in the 21st Century: The Role of Strategic Leadership. The Academy of Management Executive, Vol. 13(1), pp. 43-57.

30. Ireland, R. Duane dan Michael A. Hitt (2006). Achieving and maintainingstrategic competitiveness in the21st century: The role ofstrategic leadership. Academy of Management Executive, Vol. 19, No. 4.

31. Iwasaki, I. (2008). The determinants of board composition in transforming economy: evidence from Russia, Journal of Corporate Finance, Vol. 14 No. 5, pp. 532-549

32. Kadarwati. (2015). PengaruhPerilakuKepemimpinandanKemampuanterhadapKinerjaPemasarAsuransiJiwa. Jurnal of Economy, Vol. 3. No-1-15-27

33. Kamariah, Najmi, Abdul Rahman, Isa Ansari Kadir (2018). Mediation effect of dynamic capability in the relationship between knowledge management and strategic leadership to organizational performance accountability. International Journal of Law and Management

34. Kaplan, R. S., dan Norton, D. P. (1992). The Balanced Scorecard-Measure that drive performance. Harvard Business Review, pp. 71-90. 
35. Karim, Adiwarman. 2004. Bank IslamAnalisisFiqihdanKeuangan. Jakarta., PT Raja GrafindoPersada, pp 255.

36. Ke, W. and Wei, W.W. (2006). Organizational learning process: its antecedents and consequences in enterprise system implementation. Journal of Global Information Management, Vol. 14 No. 1, pp. 1-22.

37. Kitonga, D. M., Bichanga, W. O. danMuema, B. K. (2016). Strategic Leadership And Organizational Performance In Not-For-Profit Organizations In Nairobi County In Kenya. International Journal of Scientific \& Technology Research, Volume 5, Issue 05

38. Lauer, Sabine, Uwe Wilkesmann (2017). The governance of organizational learning - empirical evidence from best-practice universities in Germany, The Learning Organization, Vol. 24 Issue: 5

39. Leech, D., \& J. Leahy (1991). Ownership Structure, Control type Classification and the Performance of large British. Economic Journal 101, pp. 1418-1437

40. Lovell, Sharon E. (1999). Does Gender Affect The Link between Organizational Citizenship Behavior and Performance Evaluation?

41. Lynall, M.D., Golden B.R., \& Hillman, A.J. (2003). Board Compotition from adolescence to maturity: Multitheoretic view, Academy of Management Review. 12,2002, pp. 81-100

42. Luthans, F. (2002). Organizational Behavior, Ninth Edition. Singapore: McGraw-Hill International Editions.

43. Martin, C., Nyasha, M., dan Edson, V. (2014). Leadership Styles and Organizational Performance: A Case Study of LG Finances, Bindura, Zimbabwe. International Journal of Innovative Research and Development ISSN 2278-0211

44. Mason,C. dan Brown, R. (2017). Looking Inside The Spiky Bits: A Critical Review And Conceptualisation of Entrepreneurial Ecosystems. Small Business Economics, Vol. 49, No. 1, pp. 11-30.

45. Monica Ida Uniati (2014). Learning Organization, KomitmenpadaOrganisasi, KepuasanKerja, EfektifitasPenerapanSistem ISO danDampaknyaterhadapKinerjaOrganisasi (StudiKasusStafAdministrasi UK PETRA Surabaya). JurnalManajemenPemasaran, Vol. 8, No. 1, April 2014

46. Morris, M. H., Kuratko, D. F., \&Covin, J. G. (2008). Corporate Entrepreneurship \& Innovation. USA: Thomson South-Western.

47. Mowday, R. T., R. M. Steers., \& L. W. Porter (1979). The Measurement of Organizational Commitment. Journal of Vocational Behavior. 11, p.: 224-247.

48. Mujeeb, E. M., Masood, M. M. dan Ahmad, M. A. (2011). Relationship between Organizational Culture and Performance Management Practices: A Case of University in Pakistan. Journal of Competitiveness, Vol.3, No.4

49. Nikpour, A. (2017). The Impact of Organizational Culture on Organizational Performance: The Mediating Role of Employee's Organizational Commitment. International Journal of Organizational Leadership, Vol. 6, pp. 6572

50. Nthini, E. K. (2013). Effect of Strategic Leadership on The Performance of Commercial and Financial State Corporations in Kenya. University of Nairobi

51. Organ .D.W. (1990). The Motivation Basis of Organizational Citizenship Behavior .

52. Organ, D. W. \& Ryan, K. (1994), A Meta-analytic Review of Attitudinal and Dispositional Predictors of Organizational Citizenship Behavi or, Personnel Psychology, Vol. 48.

53. Owoyemi, O.O. danEkwoaba J.O. (2014). Organisational Culture: A Tool for Management to Control, Motivate and Enhance Employees' Performance. American Journal of Business and Management, Vol.3, No.3, pp. 168177

54. Ovidiu, I.D. (2014). The Link between Organizational Culture and Performance Management Practices: A Case of IT Companies from Romania. The Annals of The University of Oradea, 1130

55. Pokharel, Mohan P dan Sang Ok Choi (2015). Exploring the relationships between the learning organization and organizational performance. Management Research Review, Vol. 38 Iss 2 pp. 126 -148

56. Pryor, F. L. (2007). "Culture and Economic Systems." American Journal of Economics and Sociology, Vol. 66, No. 4 , pp. $818-855$

57. Purwosutjipto, H.M.N. (2003). PengertianPokokHukumDagang Indonesia, Jilid 6, Djambatan. Jakarta, pp.10

58. Putri, Lestari (2014) FaktorSpesifik yang menentukankinerjaperusahaanAsuransi. JurnalManajemenFakultasEkonomiUniversitasTrisakti. Volume. 1 Nomor. 2 September 2014, pp.1-20

59. Rheem, Helen (1995). The Learning Organization. Harvard Business Review, Vol. 73, No. 2, p. 10.

60. Riduwan, A. (2007). Rumus Dan Data DalamAnalisisStatistika. Bandung: PenerbitAlfabet.

61. Schein, E.H (1992). Organizational Culture and Leadership. San Francisco: Jossey- Bass Publisher.

62. Schulz, A. and Hoegl, M. (2006). Knowledge creation in new product development projects. Journal of Management, Vol. 32 No. 2, pp. 1-27.

63. Sekaran, U. (2003). Research Methods For Business. Hoboken. NJ: John Wiley \& Sons. 
64. Sellani, R.J. (1994). Organizational Lag and its Effects on Financial Performance. Production and Inventory Management Journal, pp. 35

65. Senge, Peter (1990). The Fifth Discipline: the Art and Practice of the Learning Organization. New York: Doubleday.

66. Senge, Peter. Dec. (1996). Leading Learning Organizations. Training \& Development, Vol. 50, No. 12, pp. 364.

67. Shipley, Robert dan Jason F. Kovacs (2008). Good governance principles for the cultural heritage sector: lessons from international experience. Corporate Governance: The international journal of business in society. Vol. 8 Iss 2 pp. 214 - 228

68. Storz, M. L. (1999). Malay and Chinese Values Underlying The Malaysian Business Culture. International Journal of Intercultural Relations, Vol. 23 No. 1, pp. 117-131

69. Sugiono. (2017). StatistikUntukPenelitian. Bandung: Alfabeta.

70. Sun, S. (2009). Organizational culture and its themes. International Journal of Business and Management, Vol. 3, No. 12 , pp. 137

71. Sutojo, Siswanto\& E. John Aldridge (2008). Good Corporate Governance: Tata Kelola Perusahaan Yang Sehat, Jakarta, PT. DamarMuliaPustaka.

72. Susanne Tafvelin, Ulrica von Thiele Schwarz, Henna Hasson (2017). In agreement? Leader-team perceptual distance in organizational learning affects work performance. Journal of Business Research 75, pp. 1-7

73. Tricker, R. (1984). Corporate Governance, Vermount: Gowe.

74. WD Kearney, HA Kruger (2013). A framework for good corporate governance and organizational learning - An empirical study. International Journal of Cyber Security and Digital Forensics 2(1), pp. 36-47

75. Wheeler, Bradley C. (2002). NEBIC: A Dynamic Capabilities Theory for Assessing Net-Enablement. Information Systems Research, Vol. 13, No. 2, Measuring e-Commerce in Net-Enabled Organizations, pp. 125146.

76. Wulandari, Ndaruningpuri (2006). PengaruhIndikatorMekanisme Corporate Governance terhadapKinerja Perusahaan Publik di Indonesia. FokusEkonomi. Vol. 1. no.2Desember 2006, pp. 120-136.

77. Wu, F., Zsidisin, G.A. and Ross, A.D. (2007). Antecedents and outcomes of e-procurement adoption: an integrative model. IEEE Transactions on Engineering Management, Vol. 54 No. 3, pp. 576-87.

78. Yamin, S. danKurniawan, H. (2009). Structural Equation Modeling: BelajarLebihMudahTeknikAnalisis Data KuesionerDenganLisrel-PLS. Jakarta: SalembaInfotek.

79. Zand, D. E. (2009). Strategik renewal: How an organization realigned structure with strategik. Journal of Strategik and Leadership, 37(3), pp. 23-28.

80. Zhao, Hailin, HaimengTeng, Qiang Wu. 2018. The effect of corporate culture on firm performance: Evidence from China. China Journal of Accounting Research 11, pp.1-19. 